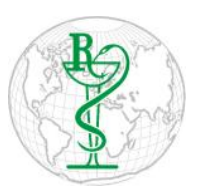

INDO GLOBAL JOURNAL OF

PHARMACEUTICAL SCIENCES

ISSN 2249- 1023

\title{
Preparation And Evaluation Of Directly Compressible Tablets Of Ketoprofen Crystals
}

\author{
Pooja D. Vaghela ${ }^{* 1}$, H.M. Tank ${ }^{2}$ \\ ${ }^{1}$ Shantilal Shah Pharmacy College, M. K. Bhavnagar University, Bhavnagar -364002, Gujarat, India \\ ${ }^{2}$ Aatmiya Institute, Rajkot, India
}

Address for Correspondence: Pooja D. Vaghela, poojavaghela786@gmail.com

Received:
14.03.2019
Accepted:
07.07 .2019
Published:
24.11 .2020

Keywords
Compressibility;
Crystallization;
Pharmacotechnic
al parameters;
manufacturability
; Directly
compressible
tablet.

Received:

14.03.2019

07.07 .2019

Published:

Keywords

Compressibility;

Crystallization;

al parameters;

manufacturability

compressible

tablet.

\begin{abstract}
Purpose: The aim of present investigation was to prepare the directly compressible tablets of Ketoprofen loaded crystals and the prepared tablets were evaluated for the improvement in drug release of Ketoprofen as compared to the pure drug. Methods: Ketoprofen crystals were prepared by solvent evaporation, a conventional method, with an excipient, saccharin sodium dihydrate at room temperature. Control batch of Ketoprofen was prepared by excluding the excipient in the preparation. The prepared crystals were converted to directly compressible tablet dosage form. Results: The crystal formation of Ketoprofen lead to improve the compressibility, mechanical properties, and tensile strength of the drug which enable to prepare directly compressible tablet dosage form. The In-vitro study demonstrated 2.71 fold increase in the drug release rate from tablets of Ketoprofen crystals compared to the pure drug after one hour. The characterization was done by Scanning Electron Microscopy (SEM), Differential Scanning Calorimetry (DSC), Powder X-Ray Diffractometry (pXRD), and Headspace Gas Chromatography (HSGC) study of Ketoprofen treated crystals illustrated the improvement in physicochemical, manufacturability, and pharmacotechnical parameters of Ketoprofen. Conclusions: The crystal engineering approach can be used to improve the physicomechanical and pharmacotechnical parameters of BCS Class-II drugs which enable to prepare directly compressible tablet dosage form. (C) 2020 iGlobal Research and Publishing Foundation. All rights reserved.
\end{abstract}

Cite this article as: Vaghela, P.D.; Tank, H.M. Preparation and evaluation of directly compressible tablets of ketoprofen crystals. Indo Global J. Pharm. Sci., 2020; 10(3): 21-34. DOI: http://doi.org/10.35652/IGJPS.2020.10303.

\section{INTRODUCTION}

Ketoprofen is a potent non-steroidal anti-inflammatory drug (NSAID) in arthritis, toothache and in the skeletal muscle pain in form of topical patches [1-3]. Ketoprofen is of BCS Class II drug which has poor aqueous solubility $[4,5]$ with high permeability. As per powder rheology, Ketoprofen is classified as a powder with poor flow property and compressibility [6-10] and hence it is not converted into directly compressible tablet dosage form by direct compression technique.

Crystallization of Ketoprofen can lead to improve its mechanical properties with compressibility which lead to prepare directly compressible tablets of Ketoprofen crystals.
Directly compressible tablets of pure drug, its control batch, and Ketoprofen loaded crystals

Improvement in the mechanical and processing parameters like flowability, packability, compactibility, and compressibility of samples under investigation enables to employ direct compression process. Hence tablets containing the pure drug, its control batch and an equivalent amount of API containing treated crystals are prepared by direct compression process by using different formulation excipients. Samples used for tableting should have a similar size range of particles. The weighed quantity of ingredient for each tablet (containing an equivalent amount of API) is introduced into the die manually and compressed into the tablet form. 
Indo Global Journal of Pharmaceutical Sciences, 2020; 10(3): 21-34

\section{Dissolution Study}

\section{In-Vitro drug release study of directly compressible tablets of pure drug, its control batch, and Ketoprofen loaded crystals}

Directly compressible tablet dosage form of API loaded crystals can be done without addition of any amount of directly compressible diluent during the tablet formulation while such type of directly compressible diluent is required to be added for the preparation of directly compressible tablet dosage form of pure drug and its control batch which clearly implies that there is an improvement in the flowability, packability, compactibility, and compressibility of API loaded crystals which enable to form directly compressible tablet dosage form.

In-vitro drug release study of directly compressible tablets of pure drug, control batch and API loaded crystals is carried out and compared to determine the improvement, if any, in the amount of drug released from the tablet dosage form of treated crystals compared to the compressed tablets of pure drug and its control batch after scheduled time intervals which furnish an idea about the effect of compression on the samples under investigation from their dissolution behavior.

\section{Dissolution parameter study of directly compressible tablets of Ketoprofen loaded crystals}

In-vitro drug release study of API loaded crystals in powder form is carried out to determine the amount of drug released after 5, 10, and 60 minutes in order to evaluate the dissolution percent and dissolution efficiency respectively and compared with the in-vitro drug release study of pure drug, and control batch at the same time interval which enable to find the improvement in the dissolution rate, dissolution percent and dissolution efficiency of the treated crystals compared to the pure drug and its control batch.

Dissolution parameters such as dissolution percent (DP5min), dissolution efficiency (\% DE10) and time required to release $50 \%$ of the drug (t50\%) in the respective dissolution medium can be determined to evaluate the solubility and dissolution behaviour of the API loaded crystals and its directly compressible tablets compared to pure drug. Khan and Rhodes had proposed the concept of dissolution efficiency (\%DE) [11]. Dissolution efficiency is a measure of the determination of in-vitro drug release data. Dissolution efficiency is defined as the area under the curve (AUC) up to a certain time ' $t$ ' determined as the percentage of the area of rectangle described by $100 \%$ drug release in the same time [12].

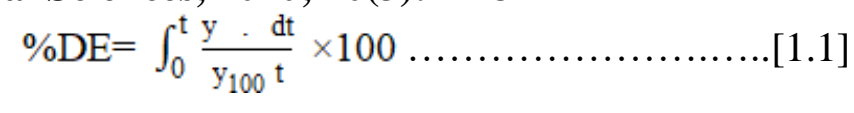

3. Statistical analysis of the dissolution profiles of directly compressible tablets of Ketoprofen loaded crystals

Statistical analysis of the dissolution profiles can be carried out by determining and comparing the similarity factor (f2) and mean dissolution time (MDTin-vitro) of the prepared formulations with pure drug in the respective dissolution medium in order to determine the mean dissolution time of the prepared formulation compared to the pure drug as well as to determine the similarity, if any, between two dissolution profiles of the samples under investigation which suggested the identical dissolution profile of the respective formulation with the pure drug. The value of similarity factor (f2) should be in between 50-100 which indicates the similarity between the two dissolution profiles under investigation.

The similarity factor $\mathrm{f} 2$ is assessed by determining the similarity in the percentage drug released between two dissolution profiles and is evaluated by the following equation:

$$
\begin{aligned}
& \mathrm{f}_{2}=50 \times \log \left[\left(1+\left(\frac{1}{n}\right) \sum_{\mathrm{t}=1}^{\mathrm{n}} \mathrm{w}_{\mathrm{t}}\left(\mathrm{R}_{\mathrm{t}}-\right.\right.\right. \\
& \left.\left.\left.\mathrm{T}_{\mathrm{t}}\right)^{2}\right)^{-0.5} \times 100\right]
\end{aligned}
$$

Where $\mathrm{n}$ is the number of withdrawal points, Rt is the percentage drug released of the reference sample at the time point $t$ and $T$ is the percentage drug released of the test sample at the time point t. Similarity factor (f2) value $100 \%$ shows the test and reference sample profiles are identical. Therefore values between 50 and 100 indicate the dissolution profiles are identical while values less than 50 indicate an increase in dissimilarity between drug release profiles.

The difference in drug release rate of pure drug and prepared formulations can be evaluated by putting the drug release data into the following equation.

$$
\mathrm{MDT}_{\text {in-vitro }}=\frac{\sum_{\mathrm{i}=1}^{\mathrm{n}} \mathrm{t}_{\text {mid }} \Delta \mathrm{M}}{\sum_{\mathrm{i}=1}^{\mathrm{n}} \Delta \mathrm{M}}
$$




\section{Indo Global Journal of Pharmaceutical Sciences, 2020; 10(3): 21-34}

Here, $\mathrm{i}$ is the number of samples, $\mathrm{n}$ is number of drug release times, $\mathrm{t}$ and tmid is time at the midpoint between the time ti and $\mathrm{ti}-1$, and $\Delta \mathrm{M}$ is the amount of drug released (mcg) between the time ti and ti-1. MDT represents the time required for the drug to release which expresses an accurate drug release rate at the specific time of dissolution. It also represents the first statistical moment for the cumulative drug release process. Higher the value of MDT represents the greater drug retarding ability [22].

\section{Characterization parameters of Ketoprofen loaded crystals}

\section{Scanning Electron Microscopy (SEM) Study}

The SEM study of the pure drug, control batch and Ketoprofen loaded crystals can be done by using scanning electron microscope at different magnification. The study is performed to determine and compare the change in particle size and shape of the samples under investigation in order to evaluate their mechanical property like flowability. Surface topography of the samples can also be analyzed by SEM study.

\section{Differential Scanning Calorimetry (DSC) Study}

The Differential scanning calorimetry study of the pure drug, control batch, excipient, physical mixture of API and excipient, and Ketoprofen loaded crystals can be done by using DSC instrument. The study can be performed to determine the melting point, enthalpy of fusion, any polymorphic transition, endothermic and exothermic phenomena of the samples under investigation.

Thermal analysis is performed for the pure drug, excipient and physical mixture of both using DSC to establish the compatibility of materials also. The characterization of treated crystal formulation can also be assessed by interpreting and comparing the DSC spectra of individual components of pure drug, control batch excipient, and physical mixture of an API and excipient.

\section{Powder X-Ray Diffractometry (pXRD) Study}

The pXRD study is performed to determine the intensities of pure drug, control batch, excipient, physical mixture of API and excipient, and Ketoprofen loaded crystal formulation at different $2 \theta$ values to characterize the crystalline behavior of respective samples and compare them to analyze the change in crystallinity in the final treated crystal formulation. The crystalline or amorphous form of the samples under investigation can be carried out by pXRD study.

\section{Headspace Gas Chromatography (HSGC) Study}

The analysis of gases in sealed cans and later to the general analysis of vapors in contact with the sample was first termed as 'headspace analysis'. The technique in combination with this analysis used was Gas chromatography and hence the technique is termed as headspace gas chromatography.

Headspace gas chromatography is most suited for the analysis of very light volatiles in samples that can be efficiently partitioned into the headspace gas volume from the liquid or solid matrix sample. Higher boiling volatiles and semivolatiles are not detectable with this technique due to their low partition in the gas headspace volume $[13,14]$.

\section{MATERIALS AND METHODS}

\section{Materials}

Ketoprofen (KETO) was gifted by Emcure Pharmaceuticals Limited, Pune and Saccharin sodium dihydrate (SAC-Na) was gifted by Pure Chem. Pvt. Ltd., Ankleshwar, Gujarat. Disodium hydrogen orthophsophate dihydrate (Na2HPO4) and Potassium dihydrogen phosphate (KH2PO4) were procured from SDFCL, Mumbai. Sodium Hydroxide $(\mathrm{NaOH})$ and Sodium acetate trihydrate were procured from Rankem, New Delhi, India. All other solvents, excipients and chemicals used were of analytical and HPLC grade (Merck Pvt. Ltd., Mumbai, India).

\section{Ketoprofen crystals prepared by solvent evaporation method}

Ketoprofen loaded crystals were prepared by conventional solvent evaporation technique using Saccharin sodium dihydrate as an excipient in the molar proportion of $1 \mathrm{M}: 1 \mathrm{M}$ which form hydrogen bonding with Ketoprofen. Crystallization of Ketoprofen lead to improve the physicochemical properties like aqueous solubility and invitro dissolution rate. A batch of control crystals was also formulated by excluding excipient and keeping all other experimental parameters same $[15,16]$.

Procedure for the preparation of directly compressible tablets of pure drug, its control batch and Ketoprofen loaded crystals

Tablets of pure drug, its control batch and Ketoprofen loaded crystals were prepared by direct compression method. All the ingredients were separately weighed and sifted using 40\# mesh. API and Mannitol were passed through a 30\# mesh. Tablets containing an equivalent amount of API was mixed gently in glass mortar using a pestle with different formulation excipients of directly compressible type and finally, the blend was lubricated with Magnesium stearate and Talc. Before 


\section{Indo Global Journal of Pharmaceutical Sciences, 2020; 10(3): 21-34}

compression, the surfaces of punches were lubricated with $2 \%$ $\mathrm{w} / \mathrm{v}$ magnesium stearate in acetone. The powder blend was directly compressed into tablets as per the formulation for the preparation of directly compressible tablets for all batches.

Directly compressible tablets of Ketoprofen loaded crystals, containing an equivalent amount of Ketoprofen, were prepared using $12 \mathrm{~mm}$ round concave faced punch of an eight-station rotary tablet machine to obtain tablets of required hardness and thickness. Compression force was kept constant for all formulations. The tablets were ejected and stored in screwcapped bottles for $24 \mathrm{~h}$ to determine possible hardening and elastic recovery. The tablets were taken for in-process and finished product evaluation tests carried out immediate after ejection and also after relaxation period of $24 \mathrm{~h}$. The tablets were studied in three replicates. The same technique was applied for the preparation of tablets of the pure drug as well as of control batch of Ketoprofen.

Evaluation Parameters of Directly Compressible Tablets of Pure Drug, its Control Batch and Ketoprofen Loaded Crystals

\section{Uniformity of Weight}

The USP XXX weight variation test was carried out by weighing 20 tablets individually of each batch separately and calculating the average weight and comparing the individual tablet weight to average weight.

\section{Thickness}

The thickness was measured by digital vernier calipers (Digimatics). The thickness of tablets for each batch was measured in $\mathrm{mm}$.

\section{Hardness Test}

Hardness was measured by Monsanto hardness tester. From each batch, ten tablets were tested. The force required to break the tablet is recorded. The hardness of tablets for each batch was measured in $\mathrm{kg} / \mathrm{cm} 2$.

\section{Friability Test}

Twenty tablets were weighed and placed in the Roche friabilator (Electrolab - EF 2, USP). The apparatus was rotated at 25 RPM for 4 minutes then the tablets were dedusted and weighed again. The percentage friability was measured for each batch.
In-Vitro drug release study of directly compressible tablets of Ketoprofen pure drug, its control batch and Ketoprofen loaded crystals (IP X)

In-vitro dissolution measurements were carried out in USP dissolution test apparatus (Electrolab Dissolution Tester TDT06P, USP). The dissolution profile of directly compressible tablets of Ketoprofen pure drug, its control batch and treated crystals were studied in $900 \mathrm{~mL}$ of Phosphate buffer $\mathrm{pH} 7.5$. The directly compressible tablets were placed in a dissolution flask containing $900 \mathrm{~mL}$ of the dissolution medium, thermostated at $37 \pm 0.5^{\circ} \mathrm{C}$, with a paddle (USP Type II) with a rotation speed of 50 RPM for one hour.

After each time interval i.e., 5, 10, 15, 20, 30, 40, 50 and 60 minutes, the samples $(5 \mathrm{~mL})$ were withdrawn and replaced immediately with fresh dissolution medium. The samples were filtered and one milliliter of the filtrate was diluted with respective buffer solution till the absorbance was measured in the range of $0.2-0.8$. All the samples were assayed similarly by measuring the absorbance spectrophotometrically at 260 $\mathrm{nm}$ wavelength for the dissolved drug. The dissolution experiments were conducted in triplicate and the mean of the absorbances was calculated. After one hour of dissolution, the amount (\%) of the Ketoprofen drug dissolved was calculated graphically and used as comparison parameter in dissolution studies.

\section{Characterization parameters}

The prepared Ketoprofen loaded crystals and control batch were characterized by comparing them with the pure drug for the following attributes:-

\section{Scanning electron microscopy (SEM) study}

Morphology and surface topography of pure drug, control batch and API loaded crystals were visualized by SEM instrument of Zeiss Evo® 18 special edition, Germany.

Dried each sample under analysis was placed on the aluminum stubs previously fixed with double-sided sticky carbon tape separately and placed each stub in their appropriate position denoted on the stage of the instrument. The analysis was done under vacuum and photographs were taken at various magnifications to observe the surface morphology, shape, and size of each sample.

\section{Differential scanning calorimetry (DSC) study}

Compatibility study and characterization of pure drug, Saccharin sodium excipient, physical mixture of drug and excipient, control batch and API loaded crystals were done by interpreting the DSC spectra of the respective samples analyzed by DSC-60, Shimadzu, Japan. The calibration was done by using Indium as standard. 


\section{Indo Global Journal of Pharmaceutical Sciences, 2020; 10(3): 21-34}

The analysis was performed under a nitrogen purging rate of $100 \mathrm{ml} / \mathrm{min}$. Accurately weighed each sample (about $3 \mathrm{mg}$ ) were placed in aluminum crucibles separately and sealed with a pin hole-pierced cover. Thermal curves were recorded at a heating rate of $10{ }^{\circ} \mathrm{C} / \mathrm{min}$ from $25{ }^{\circ} \mathrm{C}$ to $300{ }^{\circ} \mathrm{C}$ against a sealed aluminum empty crucible as a reference.

\section{Powder $x$-ray diffractometry (pXRD) study}

The crystalline state of pure drug, Saccharin sodium excipient, physical mixture of drug and excipient, control batch and API loaded crystals was confirmed with powder X-ray diffractometry (pXRD) and $\mathrm{CuK} \alpha$ radiation using Rigaku Xray Diffractometer - Ultima IV, Mumbai. The instrument was operated in $2 \theta$ scale with an angular range of $10^{\circ}$ to $80.0064^{\circ}$ at a scan rate of $0.0499^{\circ}$. The intensity of samples was compared at different diffraction patterns of $2 \theta$ values to characterize the crystalline behavior of the respective samples using a wide angle $\mathrm{X}$-ray diffractometer.

\section{Headspace gas chromatography study (HSGC)}

\subsection{Preparation of blank solution}

Blank solution was prepared by transferring $5 \mathrm{ml}$ of diluent [water:DMF (50:50)] into a headspace vial. The Polytetrafluoroethylene (PTFE) butyl septa was closed and sealed with aluminium crimp cap.

\subsection{Preparation of standard solutions}

Standard solution of Ethanol (1000 ppm) was prepared by accurately measuring ethanol $(5 \mu \mathrm{L})$ and diluted it up to $5 \mathrm{~mL}$ with diluent [Water:DMF (50:50)] while second standard solution of Ethanol (2000 ppm) was prepared by accurately measuring ethanol $(10 \mu \mathrm{L})$ and diluted it up to $5 \mathrm{~mL}$ with diluent [Water:DMF (50:50)] for quantitative determination of ethanol in standard solution. This solution was transferred into a headspace vial. The PTFE butyl septa was closed and sealed with aluminium crimp cap.

\subsection{Preparation of sample solution}

Sample solution equivalent to $503 \mathrm{mg}$ of Ketoprofen crystals, was used after dilution up to $5 \mathrm{~mL}$ with diluent [Water:DMF (50:50)] and then transferred accurately into headspace vial. The PTFE butyl septa was closed and sealed with aluminium crimp cap.

\subsection{Procedure for gas chromatography}

As per the above cited procedure, 1 vial for a blank solution, 2 vials for standard solutions (1000 ppm and $2000 \mathrm{ppm}$ ), and 1 vial for sample solution, were prepared. These sealed vials were placed in the sample magazine and headspace analyzer was started to run. Peaks were measured and chromatograms were recorded. The concentration of ethanol (volatile organic component) in the sample can be calculated as $[15,17,18]$ :

Amount of organic solvent $(\mathrm{ppm})=\frac{\mathrm{A}}{\mathrm{C}} \times$

$\frac{\mathrm{W}_{\mathrm{s}}}{\mathrm{W}_{\mathrm{t}}} \times 1,000,000$

Here, A and C are the average peak area responses of solvent in the sample and standard preparation, respectively. Ws and $\mathrm{Wt}$ are weight in $\mathrm{mg}$ of standard and test sample, respectively.

\subsection{Method parameters of HSGC for Ketoprofen loaded crystals}

Instrument: Perkin Elmer Clarus 500 (GC-FID)

Column: ZB-5 (30m*0.25mm*0.25 $\mu \mathrm{m})$

Oven program: Initial Temp: $40^{\circ} \mathrm{C}$ Hold $2.00 \mathrm{~min}$; Ramp: 10

${ }^{\circ} \mathrm{C} / \mathrm{min}$ to $150^{\circ} \mathrm{C}$ holds for $2.00 \mathrm{~min}$; Total run time: 15.00 min; Split ratio: $20: 1$; Detector: $200^{\circ} \mathrm{C}$; Injector temperature: $150^{\circ} \mathrm{C}$; Carrier Gas: N2; Pressure : 10 psi

\section{RESULTS AND DISCUSSION}

Formulation of directly compressible tablets of Ketoprofen pure drug, its control batch and Ketoprofen loaded crystals

Formulation for the preparation of directly compressible tablets of Ketoprofen pure drug, control batch and treated crystals is shown in the Table $\mathbf{1}[19,20]$.

Preparation of directly compressible tablets of Ketoprofen pure drug, its control batch and Ketoprofen loaded crystals

By comparing the formulation of the preparation of directly compressible tablet of Ketoprofen pure drug, its control batch and Ketoprofen loaded crystals, it was found that $16.25 \%$ of Microcrystalline Cellulose (MCC), a directly compressible diluent, was required to be added for the preparation of directly compressible tablets of Ketoprofen pure drug and its control batch while it was not added for the preparation of directly compressible tablets of Ketoprofen loaded crystals which clearly stated that there was a considerable improvement in the properties of drug for making directly compressible form. Therefore, it was revealed that the packability, compactibility, and compressibility of Ketoprofen loaded crystals were better than the Ketoprofen pure drug and its control batch as well. Hence Ketoprofen loaded crystals could be easily converted into conventional and most acceptable directly compressible tablet dosage form as per the formulation is shown in the Table 1. 
Indo Global Journal of Pharmaceutical Sciences, 2020; 10(3): 21-34

Table 1 Formulation for the preparation of directly compressible tablets of Ketoprofen pure drug, control batch and Ketoprofen loaded crystals

\begin{tabular}{|c|c|c|c|c|}
\hline \multirow[b]{2}{*}{$\begin{array}{c}\text { Sr. } \\
\text { No } \\
\text {. }\end{array}$} & \multirow[b]{2}{*}{ Ingredients } & \multicolumn{3}{|c|}{ Amount per tablet } \\
\hline & & $\begin{array}{c}\text { Ketoprof } \\
\text { en pure } \\
\text { drug } \\
(\mathrm{mg})\end{array}$ & $\begin{array}{c}\text { Contr } \\
\text { ol } \\
\text { batch } \\
(\mathrm{mg})\end{array}$ & $\begin{array}{c}\text { Treated } \\
\text { Crystals } \\
\text { of } \\
\text { Ketoprof } \\
\text { en (mg) }\end{array}$ \\
\hline & Ketoprofen & 100 & 100 & 100 \\
\hline 1 & $\begin{array}{l}\text { Saccharin Sodium (SAC- } \\
\mathrm{Na} \text { ) }\end{array}$ & --- & --- & 52 \\
\hline & & & & $\begin{array}{c}152 \\
\text { (equivalen } \\
\text { t to } 100 \\
\text { mg } \\
\text { Ketoprofe } \\
\text { n) }\end{array}$ \\
\hline 2 & $\begin{array}{l}\text { Microcrystalline } \\
\text { cellulose (MCC) }\end{array}$ & 65 & 65 & --- \\
\hline 3 & Crospovidone & 25 & 25 & 25 \\
\hline 4 & $\begin{array}{l}\text { Polyvinyl Pyrrolidone } \\
\text { (PVP K30) }\end{array}$ & 15 & 15 & 15 \\
\hline 5 & Aspartame & 10 & 10 & 10 \\
\hline 6 & Magnesium Stearate & 8 & 8 & 8 \\
\hline 7 & Talc & 4 & 4 & 4 \\
\hline 8 & Mannitol & 173 & 173 & 186 \\
\hline & TOTAL & 400 & 400 & 400 \\
\hline
\end{tabular}

As per the IP 2010, Vol.III, daily intake of Saccharin sodium should not be more than $5 \mathrm{mg} / \mathrm{kg}$ of body weight. In the formulation, shown in Table 1, of directly compressible tablet dosage form of Ketoprofen loaded crystals contain $100 \mathrm{mg}$ Ketoprofen and $52 \mathrm{mg}$ Saccharin sodium excipient and hence the amount of Saccharin sodium (SAC-Na) was not beyond the acceptable limit.

Evaluation parameters of directly compressible tablets Evaluation of directly compressible prepared tablets of Ketoprofen pure drug, its control batch and Ketoprofen loaded crystals were performed and the results obtained are reported in Table 2. From the results shown in the Table 2, it was found that all the parameters of tablets were good in acceptance criteria.

In-Vitro drug release study of directly compressible tablets of Ketoprofen loaded crystals

Drug release profiles of directly compressible tablets of Ketoprofen pure drug, its control batch and Ketoprofen loaded crystals were studied and the results obtained are illustrated in the Table 3. In-vitro drug release data (Table 3) and profile (Figure 1) depicted that there was a significant difference in the CPR of directly compressible tablets of Ketoprofen pure drug, its control batch and treated crystals. The CPR of the directly compressible tablets of Ketoprofen loaded crystals after one hour was maximum $53.27 \%$ with 2.71 fold while control batch tablets showed $36.32 \%$ with 1.85 fold drug release compared to Ketoprofen pure drug $19.63 \%$ drug release within one hour.

Table 2. Comparison of general parameters of directly compressible tablets of pure Ketoprofen, control batch and Ketoprofen loaded crystals

\begin{tabular}{|c|c|c|c|c|}
\hline Sr. No. & Parameters & $\begin{array}{c}\text { Pure } \\
\text { Ketoprof } \\
\text { en } \\
{[\text { KETO] }}\end{array}$ & $\begin{array}{c}\text { CONTRO } \\
\mathrm{L}[\mathrm{C}]\end{array}$ & $\begin{array}{c}\text { KETO: } \\
\text { SAC- } \\
\text { Na } \\
(1 \mathrm{M}: 1 \\
\mathrm{M}) \\
\end{array}$ \\
\hline 1 & $\begin{array}{l}\text { Weight } \\
\text { Variation } \\
(\mathrm{mg})\end{array}$ & $\begin{array}{c}407.46 \pm \\
1.81\end{array}$ & $\begin{array}{c}408.88 \pm \\
1.73\end{array}$ & $\begin{array}{r}406.39 \\
\pm 1.57\end{array}$ \\
\hline & $\pm \mathrm{SD}^{*}$ & & & \\
\hline 2 & $\begin{array}{l}\text { Thickness } \\
(\mathrm{mm}) \pm \mathrm{SD}^{*}\end{array}$ & $\begin{array}{c}2.95 \pm \\
0.06\end{array}$ & $2.9 \pm 0.08$ & $\begin{array}{c}2.85 \pm \\
0.09\end{array}$ \\
\hline 3 & $\begin{array}{l}\text { Hardness } \\
\left(\mathrm{Kg} / \mathrm{cm}^{2}\right) \pm \\
\mathrm{SD}^{*}\end{array}$ & $5.4 \pm 0.27$ & $5.4 \pm 0.14$ & $\begin{array}{l}5.6 \pm \\
0.15\end{array}$ \\
\hline 4 & $\begin{array}{l}\text { Friability (\% } \\
\text { loss) } \pm \text { SD* }\end{array}$ & $\begin{array}{c}0.23 \pm \\
0.08\end{array}$ & $0.21 \pm 0.05$ & $\begin{array}{c}0.19 \pm \\
0.07\end{array}$ \\
\hline
\end{tabular}

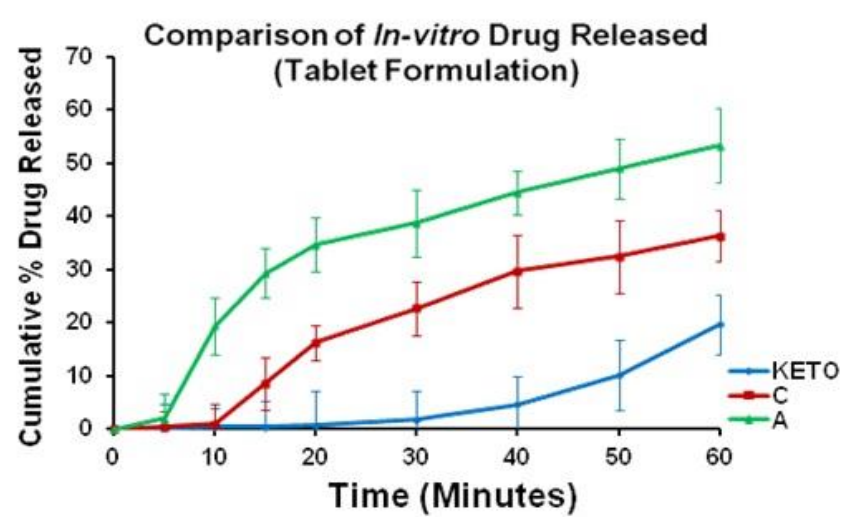

Figure 1. Comparison of In-Vitro Drug Release Profile in Phosphate Buffer pH 7.5 at $37^{\circ} \mathrm{C} \pm 0.5{ }^{\circ} \mathrm{C}$. Directly Compressible Tablets of Ketoprofen Pure Drug (KETO), Control Batch (C) and Ketoprofen Loaded Crystals with [1M:1M] (A)

The results clearly revealed that the physical properties of Ketoprofen pure drug were improved by the crystal engineering approach as there was a remarkable increase in the aqueous solubility of directly compressible tablet dosage form which was further in a correlation with the drastic increase in dissolution rate of the drug. It was also depicted that there was an improvement in the mechanical properties and compressibility of Ketoprofen loaded crystals compared to its pure drug. 


\section{Indo Global Journal of Pharmaceutical Sciences, 2020; 10(3): 21-34}

Table 3 In-Vitro dissolution profile of directly compressible tablets of Ketoprofen pure drug, control batch and Ketoprofen loaded crystals

\begin{tabular}{|c|c|c|c|}
\hline \multirow{2}{*}{$\begin{array}{c}\text { Time } \\
\text { (Minutes) }\end{array}$} & \multicolumn{3}{|c|}{ Cumulative \% Drug Released } \\
\hline & $\begin{array}{c}\text { KETO } \pm \\
\text { SD* }\end{array}$ & $\begin{array}{c}\text { CONTROL } \\
{[\mathrm{C}] \pm \mathrm{SD}^{*}}\end{array}$ & $\begin{array}{l}\text { KETO:SAC-Na } \\
(1 \mathrm{M}: 1 \mathrm{M})[\mathrm{A}] \pm \mathrm{SD}^{*}\end{array}$ \\
\hline 0 & 0 & 0 & 0 \\
\hline 5 & $0.23 \pm 4.34$ & $0.34 \pm 2.88$ & $2.00 \pm 4.74$ \\
\hline 10 & $0.35 \pm 3.44$ & $0.96 \pm 3.71$ & $19.35 \pm 5.24$ \\
\hline 15 & $0.37 \pm 4.99$ & $8.57 \pm 4.86$ & $29.27 \pm 4.64$ \\
\hline 20 & $0.59 \pm 6.68$ & $16.24 \pm 3.31$ & $34.61 \pm 5.05$ \\
\hline 30 & $1.74 \pm 5.43$ & $22.65 \pm 5.11$ & $38.67 \pm 6.40$ \\
\hline 40 & $4.70 \pm 5.33$ & $29.65 \pm 6.78$ & $44.46 \pm 4.11$ \\
\hline 50 & $10.08 \pm 6.57$ & $32.40 \pm 6.91$ & $48.99 \pm 5.62$ \\
\hline 60 & $19.63 \pm 5.54$ & $36.32 \pm 4.73$ & $53.27 \pm 6.91$ \\
\hline
\end{tabular}

* Results are mean \pm SD of three observations

Dissolution parameter study of directly compressible tablets of Ketoprofen loaded crystals

Dissolution parameters such as dissolution percent (DP5min), dissolution efficiency (\% DE10) and time to release $50 \%$ of the drug $(\mathrm{t} 50 \%)$ were determined in the medium of Phosphate buffer $\mathrm{pH}$ 7.5. The results showed (Table 4) that there was a remarkable difference in the dissolution parameters of tablets of Ketoprofen pure drug, control batch and Ketoprofen loaded crystals because Ketoprofen is practically insoluble in water while there was a noticeable improvement in the dissolution of drug from tablets of Ketoprofen crystals probably due to the formation of hydrogen bonding between the drug and excipient. Hence, there was a significant difference in the dissolution parameters of tablets of Ketoprofen loaded crystals compared to the pure drug as well as control batch.

Statistical analysis of the dissolution profiles of directly compressible tablets of Ketoprofen loaded crystals Similarity factor (f2) and mean dissolution time (MDT) were determined for the comparison of dissolution profiles of tablets of Ketoprofen loaded crystals with pure drug and its control batch studies at Phosphate buffer $\mathrm{pH}$ 7.5. From the results of Table 5, it was seen that there was no any similarity (f2 < 50) by comparing the dissolution profiles of tablets of Ketoprofen pure drug with Ketoprofen loaded crystals and control batch. Ketoprofen is practically insoluble in water while in case of control batch, an improvement in the dissolution was seen. In case of directly compressible tablets of Ketoprofen loaded crystals, there was a drastic improvement in the dissolution of the drug was observed. Hence, there was no any similarity by comparing the dissolution profile of tablets of Ketoprofen pure drug with its control batch as well as Ketoprofen loaded crystals.
Table 4 Dissolution parameters for directly compressible tablets of Ketoprofen loaded crystals

\begin{tabular}{cccc}
\hline \multirow{2}{*}{ Sample } & \% DE & $\mathbf{D P}_{\mathbf{5} \text { min }}, \boldsymbol{\%}$ & min \\
\cline { 2 - 4 } & Tablet formulation & $\begin{array}{c}\text { Tablet } \\
\text { formulation }\end{array}$ & $\begin{array}{c}\text { Tablet } \\
\text { formulat } \\
\text { ion }\end{array}$ \\
\hline $\begin{array}{c}\text { Ketoprofen } \\
\text { pure drug } \\
\text { Control } \\
\text { batch }\end{array}$ & 0.354 & 0.233 & -- \\
$\begin{array}{c}\text { Treated } \\
\text { crystals }\end{array}$ & 0.961 & 0.336 & --- \\
\hline
\end{tabular}

MDT value was less for tablets of Ketoprofen loaded crystals and control batch compared to Ketoprofen pure drug because of the improvement in the aqueous solubility as well as invitro drug release study for directly compressible tablets of crystals [22].

Table 5 Value of $f_{2}$ and MDT for directly compressible tablets of Ketoprofen loaded crystals

\begin{tabular}{ccc}
\hline \multirow{2}{*}{ Sample } & $\mathbf{f}_{\mathbf{2}}$ & MDT, min \\
\cline { 2 - 3 } & Tablet formulation & Tablet formulation \\
\hline Ketoprofen & -- & 46.981 \\
pure drug & 40.471 & 24.225 \\
Control batch & 30.325 & 16.309 \\
Treated crystals &
\end{tabular}

\section{Characterization parameters}

1. Scanning Electron Microscopy (SEM) study

SEM study was performed to identify and compare the morphology of pure Ketoprofen drug (Figure 2), control batch (Figure 3) and Ketoprofen loaded crystals (Figure 4). Scanning electron images were taken at different magnifications of the samples.

Scanning electron image of pure Ketoprofen drug illustrated the smaller size and irregular shape of the drug. Moreover, it was also found that the pure drug was appeared as an agglomerated form because of charge distribution on its surface which resulted into the very poor flow of the drug [23, 24].

Images of control batch suggested that increase in the size of particles might improve the flowability compared to the Ketoprofen pure drug [25]. 
Indo Global Journal of Pharmaceutical Sciences, 2020; 10(3): 21-34
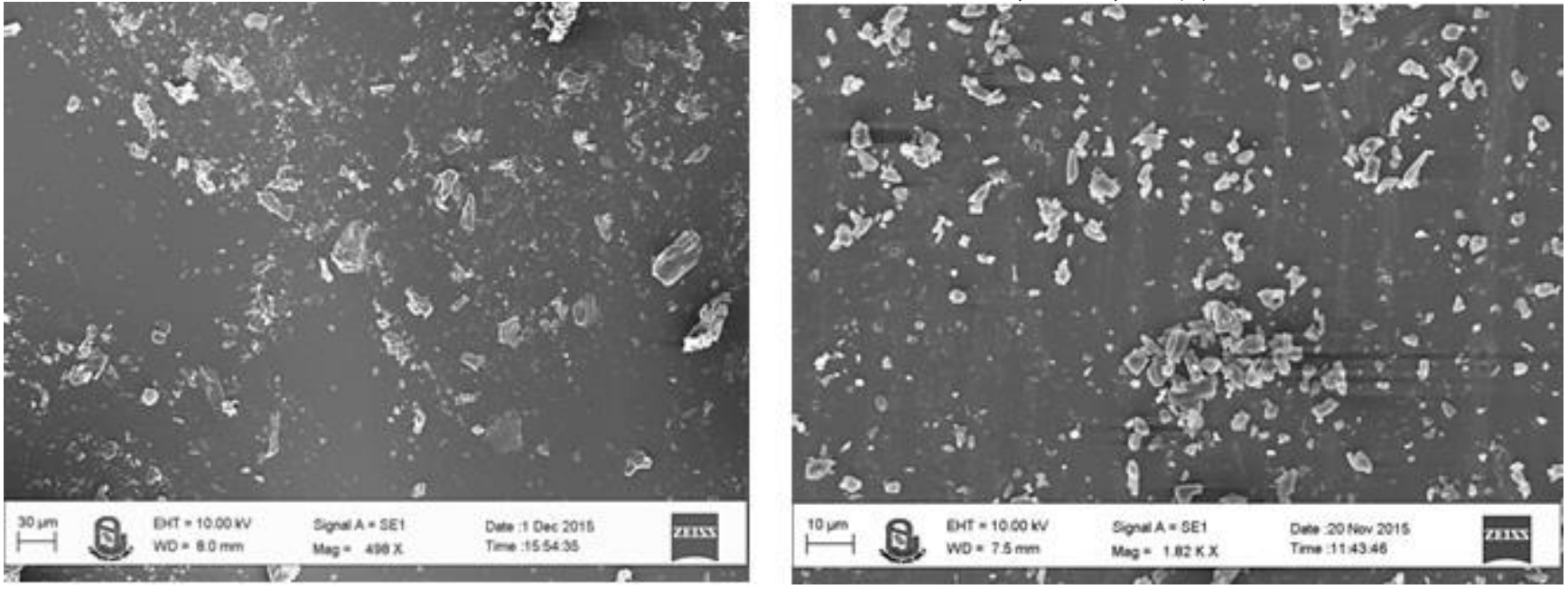

Figure 2. Scanning Electron Microscopy of Pure Drug Ketoprofen
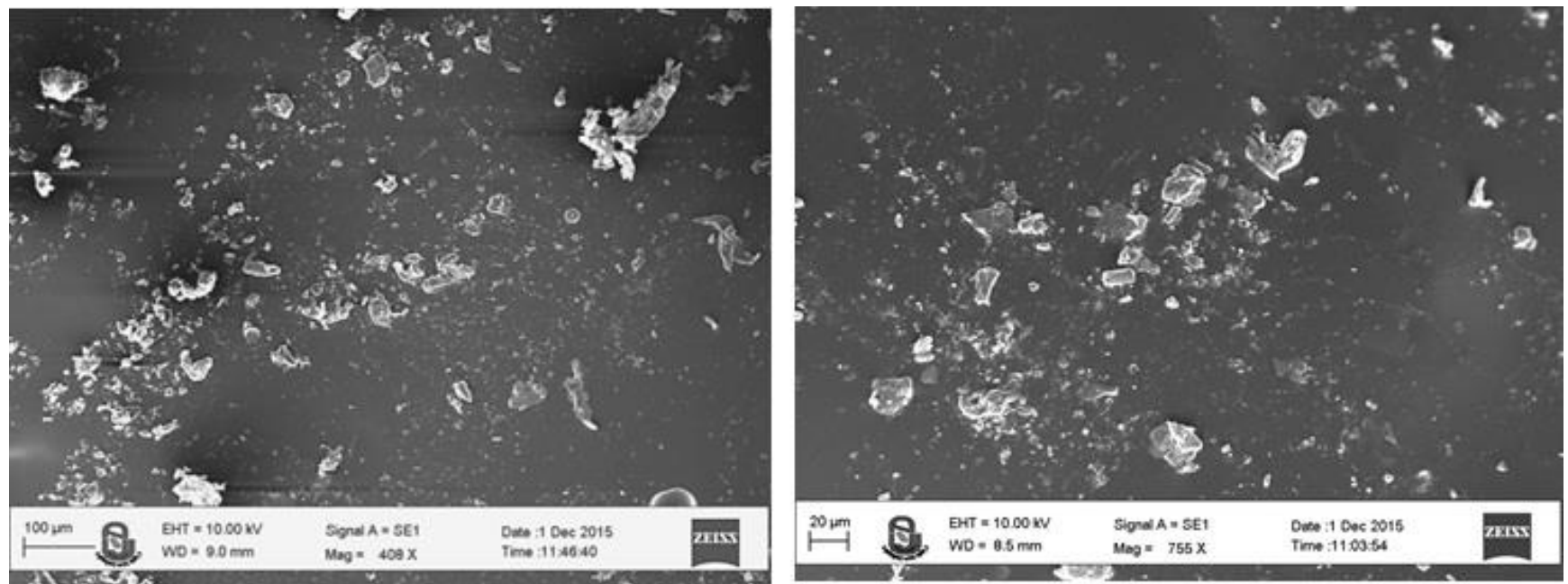

Figure 3. Scanning Electron Microscopy of Control Batch
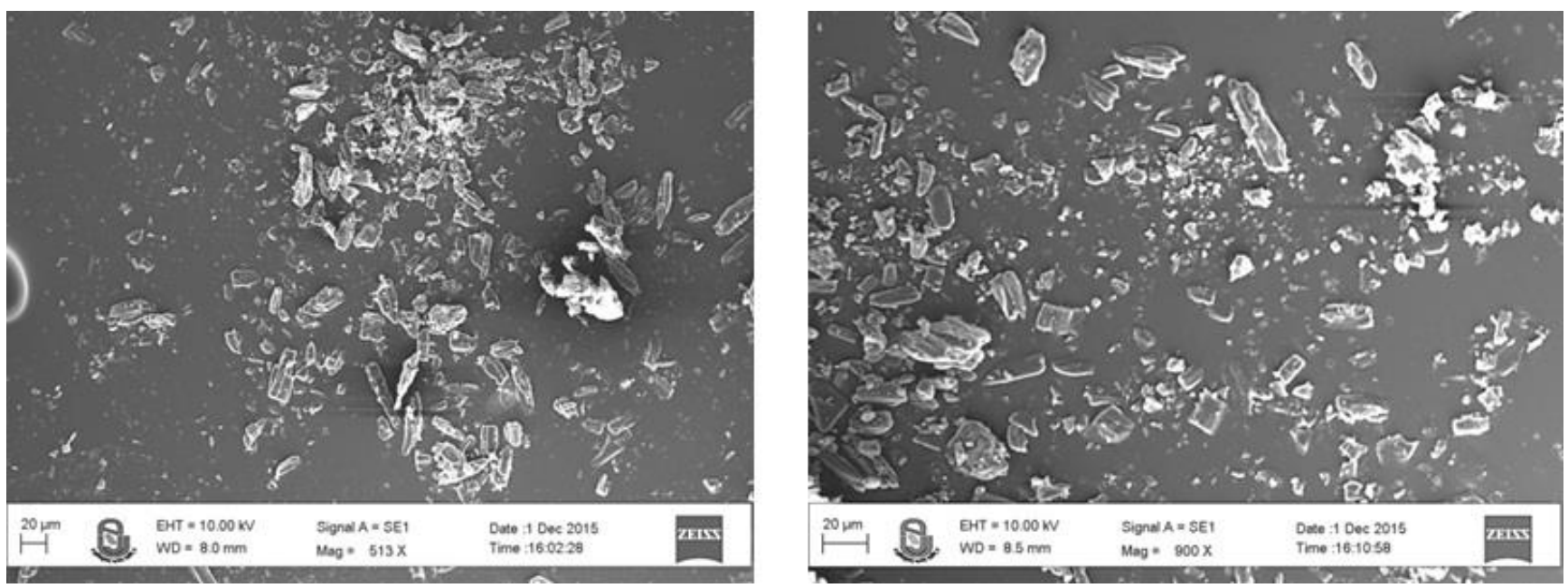

Figure 4. Scanning Electron Microscopy of Treated Crystal Formulation 
Indo Global Journal of Pharmaceutical Sciences, 2020; 10(3): 21-34

Table Data Analysis of Ketoprofen Crystals by HSGC

\begin{tabular}{|c|c|c|c|c|c|}
\hline $\begin{array}{l}\text { Sr. } \\
\text { No. }\end{array}$ & $\begin{array}{c}\text { Name of } \\
\text { Sample } \\
\text { mixed } \\
\text { with } \\
\text { Diluent } \\
\end{array}$ & $\begin{array}{c}\text { Peak } \\
\text { of } \\
\text { EtO } \\
\text { H at }\end{array}$ & $\begin{array}{c}\text { Any } \\
\text { other } \\
\text { peak } \\
\text { observed }\end{array}$ & $\begin{array}{c}\text { Observatio } \\
\text { n of EtOH } \\
\text { peak }\end{array}$ & Inference \\
\hline 1 & $\begin{array}{l}\text { Blank } \\
\text { (Only } \\
\text { Diluent } \\
\text { without } \\
\text { EtOH) }\end{array}$ & --- & $\begin{array}{l}\text { Peak of } \\
\text { Diluent is } \\
\text { observed } \\
\text { at } 6.84\end{array}$ & $\begin{array}{l}\text { EtOH peak } \\
\text { not } \\
\text { observed }\end{array}$ & $\begin{array}{l}\text { EtOH is } \\
\text { absent in } \\
\text { Blank } \\
\text { sample }\end{array}$ \\
\hline 2 & $\begin{array}{c}\text { Standard } 1 \\
(\text { EtOH } \\
1000)\end{array}$ & 3.05 & $\begin{array}{l}\text { Peak of } \\
\text { Diluent is } \\
\text { observed } \\
\text { at } 6.85\end{array}$ & $\begin{array}{l}\text { EtOH peak } \\
\text { observed }\end{array}$ & $\begin{array}{l}\text { EtOH is } \\
\text { present in } \\
\text { Standard1 } \\
\text { sample }\end{array}$ \\
\hline 3 & $\begin{array}{c}\text { Standard2 } \\
(\text { EtOH } \\
2000)\end{array}$ & 3.04 & $\begin{array}{l}\text { Peak of } \\
\text { Diluent is } \\
\text { observed } \\
\text { at } 6.84\end{array}$ & $\begin{array}{l}\text { EtOH peak } \\
\text { observed }\end{array}$ & $\begin{array}{l}\mathrm{EtOH} \text { is } \\
\text { present in } \\
\text { Standard2 } \\
\text { sample }\end{array}$ \\
\hline 4 & $\begin{array}{l}\text { Ketoprofe } \\
\text { n crystals } \\
(1 \mathrm{M}: 1 \mathrm{M})\end{array}$ & --- & $\begin{array}{l}\text { Peak of } \\
\text { otherthan } \\
\text { EtOH } \\
\text { compone } \\
\text { nt is } \\
\text { obseved } \\
\text { at } 6.54 \\
\text { Peak of } \\
\text { Diluent is } \\
\text { observed } \\
\text { at } 6.84\end{array}$ & $\begin{array}{l}\text { EtOH peak } \\
\text { not } \\
\text { observed }\end{array}$ & $\begin{array}{l}\text { EtOH is } \\
\text { absent in } \\
\text { the } \\
\text { Ketoprofe } \\
\text { n crystals }\end{array}$ \\
\hline
\end{tabular}

Scanning electron image of Ketoprofen loaded crystals showed a remarkable change in the appearance of the particles with platy shaped equidimensional crystals of larger size. It was an indication of the modification in the mechanical properties of Ketoprofen pure drug [26, 27]. Moreover, the Ketoprofen loaded crystals was not cohesive in nature. Thus, the flow properties were improved [28].

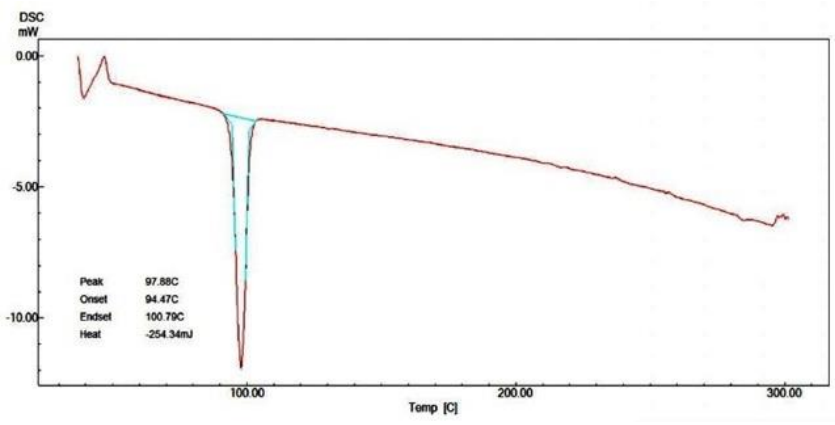

Figure 5. DSC Spectra of Ketoprofen Pure Drug
2. Differential Scanning Calorimetry (DSC) study

DSC thermogram of pure Ketoprofen drug (Figure 5), Control batch (Figure 6), Saccharin sodium (Figure 7), Physical mixture of KETO and SAC-Na in 1:1 molar ratio (Figure 8) and treated crystal formulation in 1:1 molar ratio of KETO:SAC-Na (Figure 9) are illustrated respectively.

The DSC thermograms for Ketoprofen pure drug showed sharp melting endothermic peaks at $97.88{ }^{\circ} \mathrm{C}(\Delta \mathrm{Hf}=-254.95$ $\mathrm{mJ}$ ). The sharp peak suggests the crystalline nature of the sample.

The thermogram of control batch showed an endothermic melting peak at $96.65^{\circ} \mathrm{C}(\Delta \mathrm{Hf}=-232.96 \mathrm{~mJ})$.

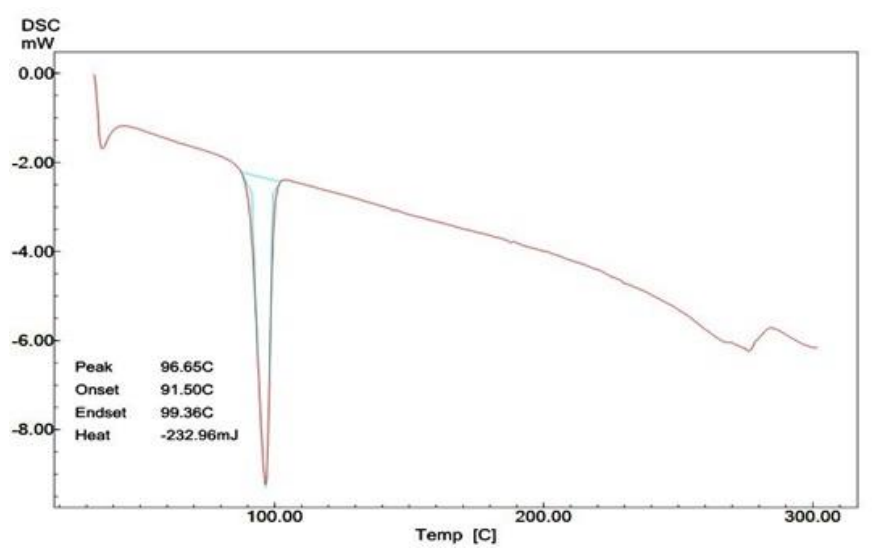

Figure 6. DSC Spectra of Control Batch of Ketoprofen

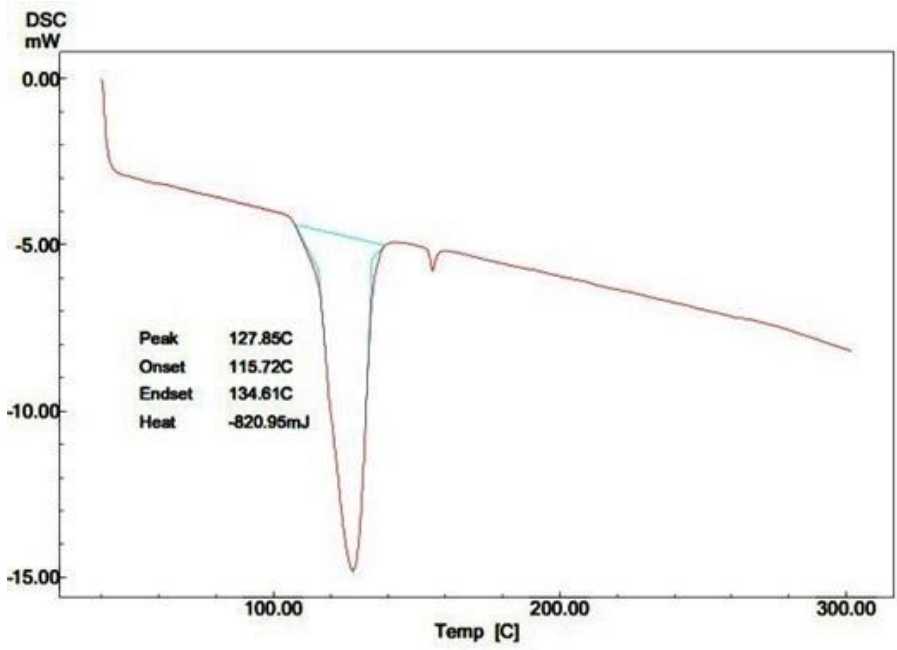

Figure 7. DSC Spectra of Saccharin Sodium Excipient 


\section{Indo Global Journal of Pharmaceutical Sciences, 2020; 10(3): 21-34}

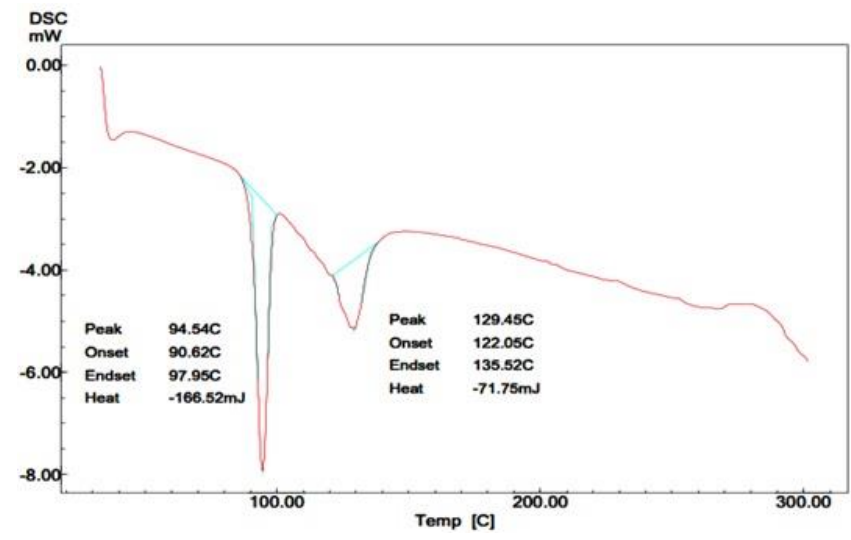

Figure 8. DSC Spectra of Physical Mixture of KETO:SACNa [1M:1M]

Thermogram of Excipient Saccharin sodium demonstrated an endothermic melting peak at $127.85{ }^{\circ} \mathrm{C}(\Delta \mathrm{Hf}=-820.95 \mathrm{~mJ})$ which is an agreement with the reported melting point of Saccharin sodium.

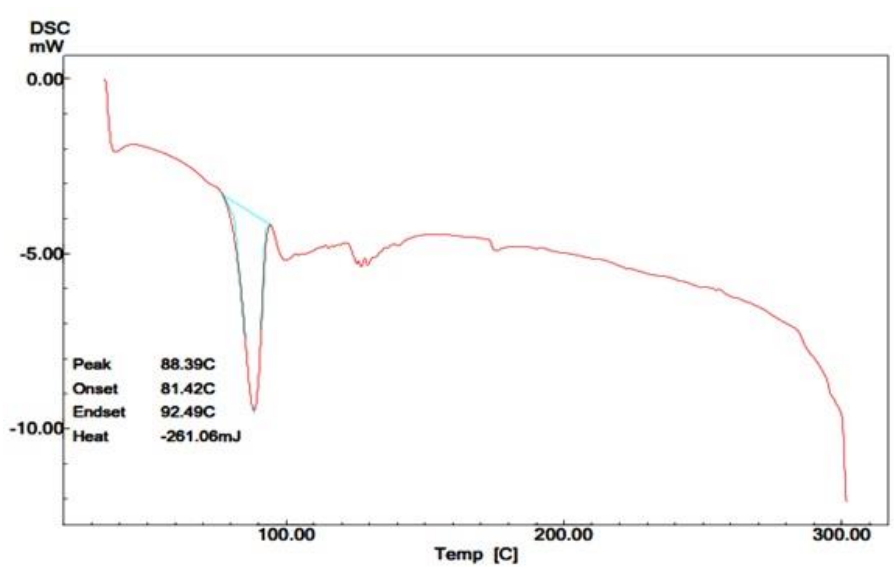

Figure 9. DSC Spectra of Ketoprofen Loaded Crystals

The compatibility of Ketoprofen pure drug and Saccharin sodium excipient was further confirmed by comparing their respective DSC spectra with their physical mixture. DSC thermogram illustrated that physical mixture showing almost similar identical melting endotherm which indicates that there was no any interaction between the drug and excipient. The melting peak of the drug was shifted might be due to mixing with an excipient.

The DSC thermogram for KETO:SAC-Na [1M:1M] treated crystals showed endothermic sharp melting behavior with a sharp peak at $88.39{ }^{\circ} \mathrm{C}(\Delta \mathrm{Hf}=-261.06 \mathrm{~mJ})$. The downward shift or drastic depression in the endothermic peak of the drug also indicated the interaction of the drug with Saccharin sodium [29]. It might be possible that the interaction of
Ketoprofen and Saccharin sodium lead to the formation of hydrogen bonding which contributed to improving the aqueous solubility of Ketoprofen [30].

The thermal behavior of treated crystal was distinct and unique from the individual components, suggests the formation of new Ketoprofen-Saccharin sodium treated crystal phase [31]. A single endothermic transition of treated crystal demonstrates the stability of the phase until the melting point and indicates the absence of any unbound or absorbed solvent.

Moreover, the melting endotherm of the treated crystal was quite shorten compared to the pure drug, perhaps due to the formation of a new crystal phase with the greater disorder in the crystal structure happened during solvent evaporation process with excipient owing to the interaction through hydrogen bonding between Ketoprofen pure drug and Saccharin sodium excipient [32].

\section{Powder X-Ray Diffractometry (pXRD) study}

Powder X-ray diffraction pattern of Ketoprofen pure drug, Control batch, Saccharin Sodium excipient, Physical mixture of Ketoprofen and Saccharin Sodium in a molar proportion of 1:1 and Ketoprofen loaded crystal formulation were recorded as illustrated in the diffraction patterns (Figure 10). In case of Ketoprofen pure drug, pXRD spectra revealed high intensity reflections with characteristic sharp peaks at $13.1912^{\circ}$, $14.3879^{\circ}, 17.3297^{\circ}, 18.3768^{\circ}, 20.0223^{\circ}, 22.9143^{\circ}, 23.9614^{\circ}$, $27.1526^{\circ}$ and $29.4462^{\circ}(2 \theta)$.

Recrystallized Ketoprofen (Control batch) from ethanol (95\%) showed different $\mathrm{pXRD}$ pattern compared to pure drug. $\mathrm{pXRD}$ spectra of recrystallized Ketoprofen showed highest intense peaks at $18.327^{\circ}$ and $22.8644^{\circ}$ which were high intense peaks with the pure drug. Moreover, the next higher intensity peak was observed at $14.4377^{\circ}(2 \theta)$. Theta region between $10^{\circ}$ to $50^{\circ}$ was almost same as pure drug and revealed that all peaks were slightly shifted which might be an evidence of retention of crystalline nature of the drug. The thermogram of control batch sample in DSC also showed a slight difference in endothermic peak compared to pure drug.

Saccharin Sodium diffractogram exhibited a distinct pattern with diffraction peaks at $11.3961^{\circ}, 12.1441^{\circ}, 16.0333^{\circ}$, $16.8311^{\circ}, 18.0278^{\circ}, 20.6705^{\circ}, 22.9641^{\circ}, 24.7592^{\circ}, 25.6068^{\circ}$, $27.352^{\circ}, 28.3991^{\circ}, 29.3465^{\circ}, 30.7426^{\circ}, 31.1415^{\circ}, 35.0308^{\circ}$, $36.1776^{\circ}, 43.3079^{\circ}$ and $46.898^{\circ}(2 \theta)$. Diffractogram physical mixture of KETO:SAC-Na in $1 \mathrm{M}: 1 \mathrm{M}$ proportion (Figure 10) showed the characteristic peaks of the pure components at nearby identical angles, which proved that no interactions took 


\section{Indo Global Journal of Pharmaceutical Sciences, 2020; 10(3): 21-34}

place during mixing. Crystals of Ketoprofen-Saccharin sodium from ethanol (95\%) showed different pXRD pattern compared to its pure components. pXRD spectra of treated crystals showed highest intense peaks at $18.4267^{\circ}, 22.9641^{\circ}$ and $24.4101^{\circ}$ which were a shift in principal peaks compared to Ketoprofen pure drug as well as Saccharin sodium. Theta region between $10^{\circ}$ to $50^{\circ}$ of Ketoprofen loaded crystals was different compared to Ketoprofen pure drug and Saccharin sodium with the appearance of new intense peaks at $20.4212^{\circ}$, $24.4101^{\circ}, 24.9088^{\circ}, 33.5848^{\circ}, 43.0586^{\circ}$ and $46.0004^{\circ}(2 \theta)$. It might be an evidence of the generation of a new crystal phase which was in good agreement with DSC endotherm of the treated crystals. The thermogram of treated crystal sample in DSC also showed differences in endotherm compared to pure components.

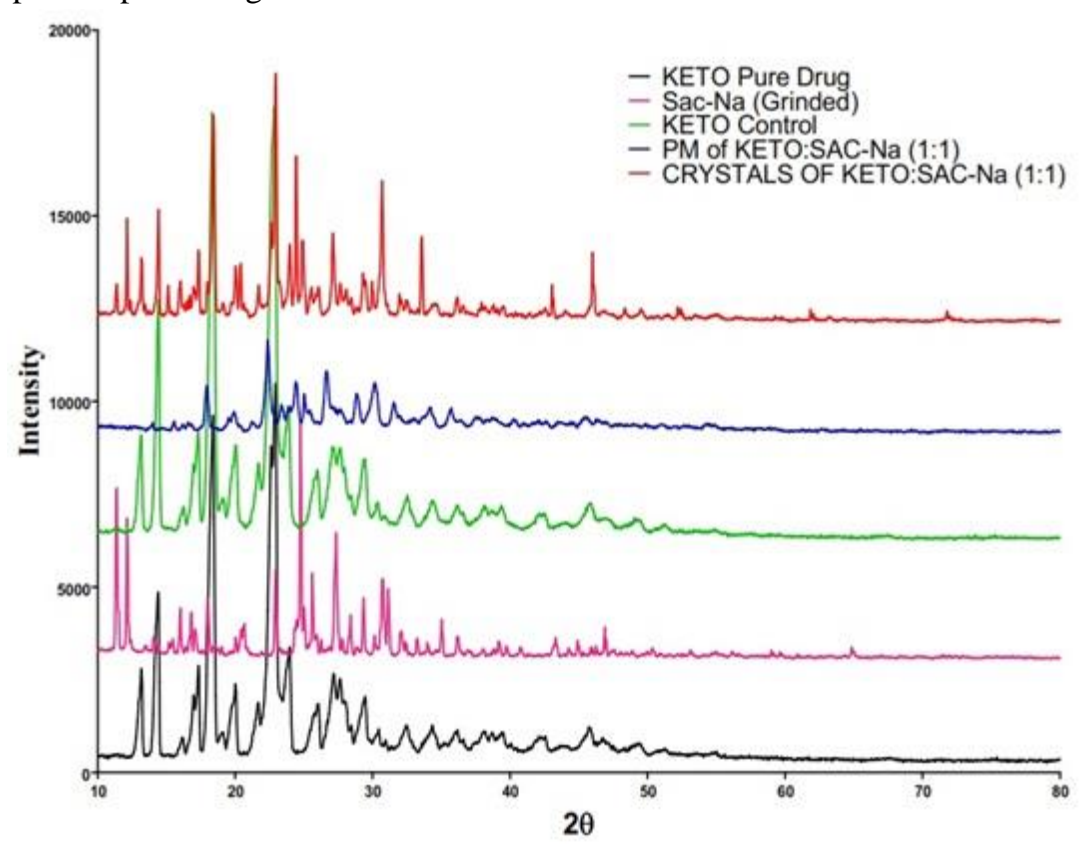

Figure 10. Comparison of pXRD pattern of Ketoprofen, Saccharin sodium, Control batch, Physical mixture and Ketoprofen loaded crystals

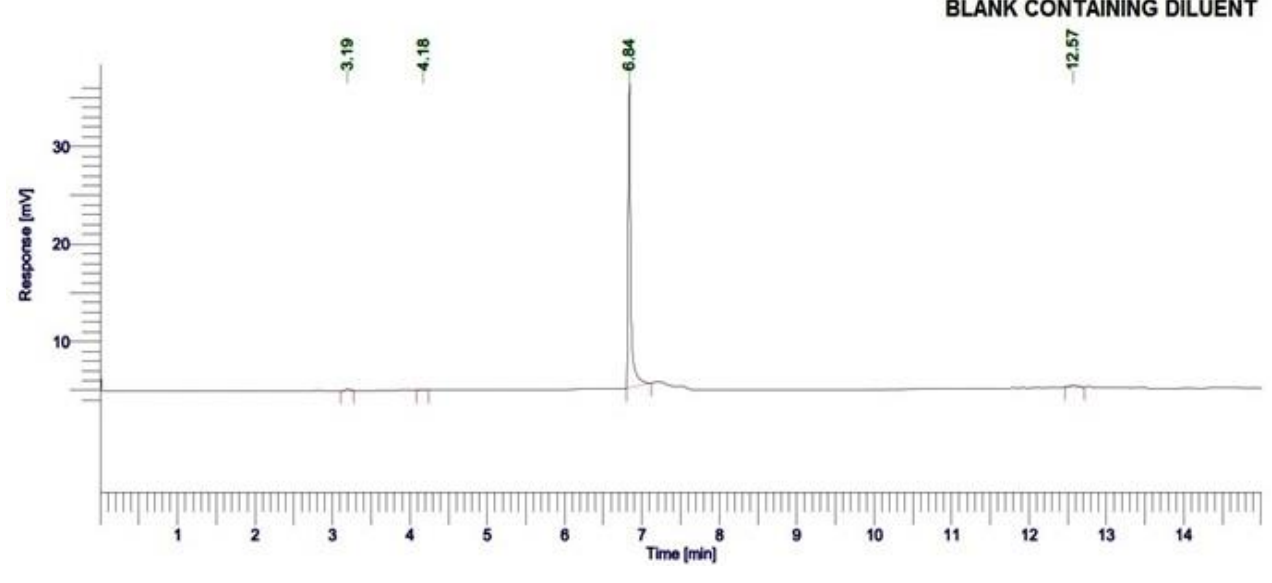

Figure 11. Chromatogram of Blank Sample Containing Diluent, Water:DMF (50:50), by HSGC 
Indo Global Journal of Pharmaceutical Sciences, 2020; 10(3): 21-34

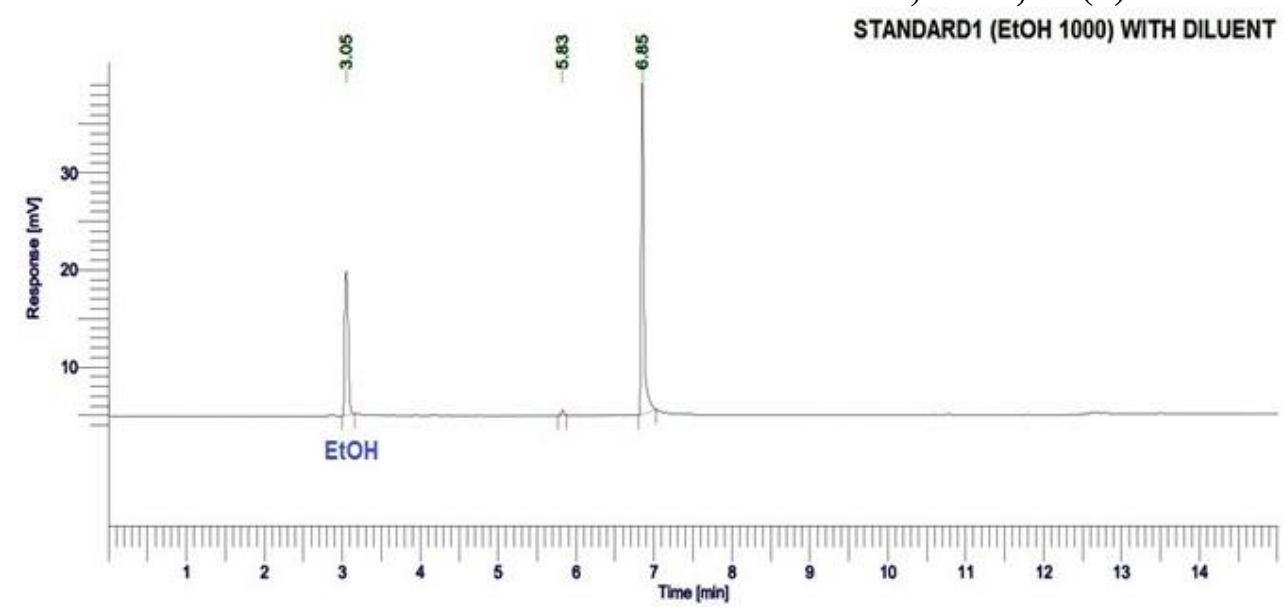

Figure 12. Chromatogram of Standard1 by HSGC

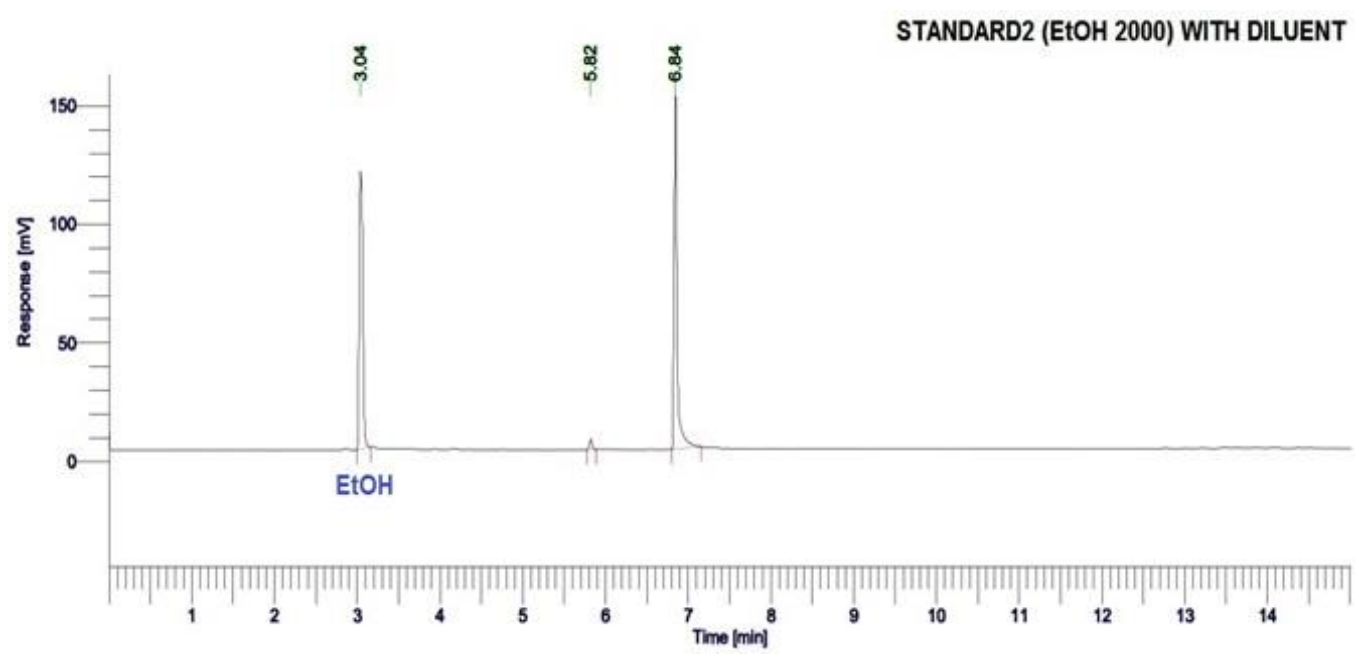

Figure 13. Chromatogram of Standard2 by HSGC

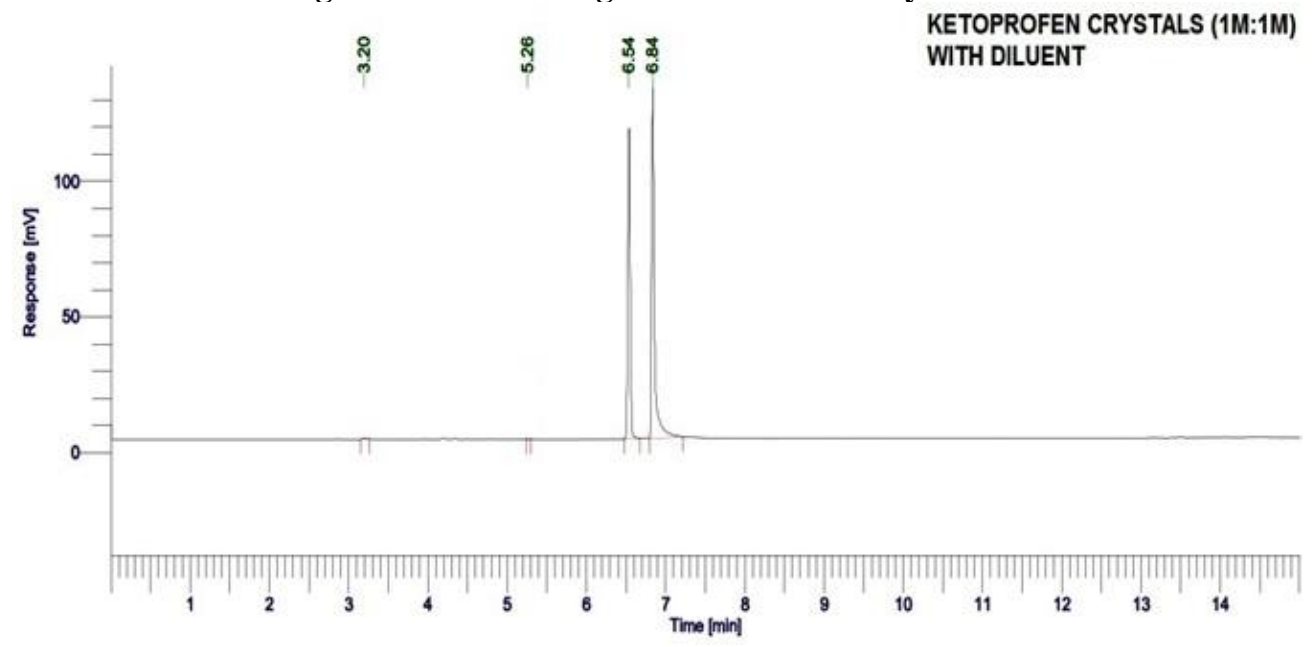

Figure 14. Chromatogram of Ketoprofen Crystals by HSGC 


\section{Indo Global Journal of Pharmaceutical Sciences, 2020; 10(3): 21-34}

4. Headspace Gas Chromatography (HSGC) study

For determining the presence and amount of Ethanol (EtOH), if any, in the treated crystals, the analysis was done by HSGC (Headspace Gas Chromatography). The Figures 11 to 14 and Table 6 clearly suggested that there was no any Ethanol solvent present in the Ketoprofen loaded crystals.

\section{CONCLUSION}

Ketoprofen is a BCS Class II drug having poor flowability and manufacturability. In the present research, directly compressible tablets of Ketoprofen crystals were prepared by crystallization technique which suggested improvement in the compressibility, mechanical properties, and tensile strength of Ketoprofen crystals compared to the pure drug. It was found

that for the preparation of treated crystals tablets, there was not required to add any amount of directly compressible diluent while the same was required to be added in the preparation of tablets of control batch and pure drug to enable it into directly compressible form. The dissolution of treated crystals as well as its tablets shown greater improvement in the dissolution profile compared to the pure drug. The characterization was carried out by SEM, DSC, pXRD and HSGC study suggested improvement in the physicochemical, mechanical and pharmacotechnical parameters of treated crystals compared to the pure drug.

\section{ACKNOWLEDGEMENT}

The authors greatly acknowledge Emcure Pharmaceuticals Limited, Pune, India and Pure Chem. Pvt. Ltd., Ankleshwar, Gujarat, India for providing the gift samples of Ketoprofen and Saccharin sodium dihydrate, respectively. Authors are also extend the sincere gratitude to the Principal, B. K. Mody Government Pharmacy College, Rajkot and the HOD, Department of Pharmaceutical Sciences, Rajkot for assistance in the present research work by providing various instrumental facilities. This work was supported and funded by the Gujarat Council on Science and Technology (GUJCOST), Gandhinagar (Ref. No. GUJCOST/MRP/2014-15/2565, Dated $30 / 03 / 2015$ ) and the authors are very much grateful for their kind financial assistance in the present research.

\section{DATA AVAILABILITY}

Not declared.

\section{CONFLICTS OF INTEREST}

\section{FUNDING SOURCE}

No external funding declared.

\section{REFERENCES}

1. Mazières, B., Rouanet, S., Guillon, Y., Scarsi, C., Reiner, V. Topical ketoprofen patch in the treatment of tendinitis: a randomized, double blind, placebo controlled study. J. of rheumatology, 2005; 32(8): 1563-1570.

2. Mazières, B. Topical ketoprofen patch. Drugs in R \& D, 2005; 6(6): 337-344.

3 . Sekiya, I. et al. Ketoprofen Absorption by Muscle and Tendon after Topical or Oral Administration in Patients Undergoing Anterior Cruciate Ligament Reconstruction. AAPS Pharm. Sci. Tech., 2010; 11(1): 154-158.

4. Amit, K., Mahalaxmi, R., Srinivas, P., Deepak, K. Enhancement of solubility and dissolution of poorly soluble drug: Ketoprofen as a model drug. J. Chem. Pharm. Res., 2011; 3(1): 268-276.

5. Khan, J. et al. Development and validation of a simple high performance liquid chromatographic method for determination of Ketoprofen in human plasma. Int. J. of Pharm. Studies and Res., 2011; 2(4): 1-5.

6. Dixit, M., Kulkarni, P.K., Kini, A.G. Spherical agglomeration of ketoprofen by solvent change method. Int. J. of Pharm. Sci. Rev. and Res., 2010; 4(3): 129-135.

7. Dixit, M., Kulkarni, P.K., Anis, S., Kini, A.G. Preparation and characterization of spherical agglomerates of ketoprofen by neutralization method. Int. J. of Pharm. and Bio Sci., 2010; 1(4): 395-406.

8. Dixit, M., Kulkarni, P.K., Gowtham, V., Shivakumar, H.G. Preparation and characterization of spray dried microparticle and chilled spray dried particle of ketoprofen by spray drying method. Asian J. of Pharm. and Cli. Res., 2011; 4(1): 138-142.

9. Nagar, G., Luhadiya, A., Agrawal, S., Dubey, P.K. Solubility enhancement of a poorly aqueous soluble drug ketoprofen using solid dispersion technique. Der. Pharmacia Sinica, 2011; 2(4): 67-73.

10. Chavda, V., Maheshwari, R.K. Tailoring of ketoprofen particle morphology via novel crystallo-co-agglomeration technique to obtain a directly compressible material. Asian J. of Pharm., 2008; 2(1): 61-67.

11. Dahiya, S. Studies on formulation development of a poorly water soluble drug through solid dispersion technique. Thai. J. Pharm. Sci., 2010; 34: 77-87.

12. Anderson, N.H., Bauer, M., Boussac, N., Khan-Malek, R., Munden, P., Sardaro, M. An evaluation of fit factors and dissolution efficiency for the comparison of in- vitro dissolution profiles. J. Pharm. Biomed. Anal., 1998; 17: 811-822.

13. A Technical Guide for Static Headspace Analysis using GC, Restek: Freude an Chromatografie. www.restekgmbh.de; 1-20.

14. Kolb, B. Chromatography Gas: Headspace gas chromatography. Academic press, 2000; 489-496.

15. Raval, M.K., Vaghela, P.D., Vachchani, A.N., Sheth, N.R. Role of excipients in the crystallization of Albendazole. Advan. Powd. Tech., 2015; 26: 1102-1115.

16. Vaghela, P.D., Tank, H.M., Chavda, J.R., Shah, P.I., Tank, P.H. Improvement of Physicomechanical and Pharmacotechnical Parameters of Ketoprofen crystals, in: Proc. of RK University's First International Conference on Research \& Entrepreneurship, 2016; 579-600. 


\section{Indo Global Journal of Pharmaceutical Sciences, 2020; 10(3): 21-34}

17. Reddy, P.B., Reddy, M.S. Residual Solvents Determination by HSGC with Flame Ionization Detector in Omeprazole, Pharmaceutical formulations. Int. J. of Pharm. Tech. Res., 2009; 1(2): 230-234

18. Paul, S.D., Mazumder, R., Bhattacharya, S., Jha, A.K. Method development and validation for the determination of residual solvents in ophthalmic nanoparticle suspension. World J. of Pharm. and Pharmaceutical Sci., 2013; 2(6): 5802-5810.

19. Rane, D.R., Gulve, H.N., Patil, V.V., Thakare, V.M., Patil, V.R. Formulation and evaluation of fast dissolving tablet of albendazole. Int. Current Pharm. J., 2012; 10: 311-316.

20. Khokra, S., Parashar, B., Dhamija, H.K., Purohit, R., Chandel, A. Formulation development and evaluation of chewable tablet of albendazole by different techniques. Int. J. Pharm. Sci., 2012; 4(1): 461-464.

21. Indian Pharmacopoeia 2010, Saccharin Sodium; Volume III: 1820

22. Patel, R., Bhimani, D., Patel, J., Patel, D. Solid-state characterization and dissolution properties of ezetimibe-cyclodextrins inclusion complexes. J. Incl. Phenom. Macrocyclic Chem., 2008; 60: 241-251.

23. Castro, S., Bruni, S.S., Lanusse, C., Allemandi, D., Palma, S. Improved Ibuprofen Dissolution Rate in Pluronic 188 Solid Dispersions. AAPS Pharm. Sci. Tech., 2010; 11(4): 1518-1525.

24. Cavalcanti, N.C.T., Giovana, D.S., Maria, A.M.T., Jose, L.S.S., Leila, B.L., Davi, P.S. Assay and physicochemical characterization of the antiparasitic Ibuprofen. Braz. J. of Pharma. Sci., 2012; 48(2): 281-290.

25. Mallick, S. Effect of solvent and polymer additives on crystallization. Ind. J. Pharm. Sci., 2004; 66: 142-147.

26. Kawashima, Y., Cui, F., Takeuchi, H., Niwa, T., Hino, T., Kiuchi, K.J. Parameters determining the agglomeration behavior and the micromeritic properties of spherically agglomerated crystals prepared by the spherical crystallization technique with miscible solvent systems. Int. J. Pharm., 1995; 119: 139-147.

27. Paradkar, A.R., Pawal, A.P., Chordiva, A.P., Patil, V.A., Ketkar, A.R. Spherical crystallization of celecoxib. Drug Dev. Ind. Pharm., 2002; 28: 1213-1220.

28. Raval, M.K., Sorathiya, K.R., Chauhan, N.P., Patel, J.M., Parikh, R.K., Sheth, N.R. Influence of polymers/excipients on development of agglomerated crystals of secnidazole by crystallo-coagglomeration technique to improve processability. Drug Devel. and Indust. Pharm., 2013; 39(3): 437-446.

29. Patil, S.A., Kuchekar, B.S., Chabukswar, A.R., Jagdale, S.C. Formulation and Evaluation of Extended-Release Solid Dispersion of Metformin Hydrochloride. J. Young Pharm., 2010; 2(2): 121-129.

30. Parmar, V.K. Master's thesis, Studies of physicochemical properties of active pharmaceutical ingredient and its modification for improvement of its functionality. The Gujarat University, 2010.

31. Gao, Y., Zu, H., Zhang, J. Enhanced dissolution and stability of adefovir dipivoxil by cocrystal formation. J. Pharm. Pharmacol., 2011; 63: 483-490.

32. Patel, V.P., Parikh, R.K., Gohel, M.C., Desai, T.R., Bhimani, D.R., Tirgar, P.R. In vitro dissolution enhancement of albendazole by preparation of inclusion complexes with HP- $\beta$ Cyclodextrin. Pharma. Sci. Monitor, 2011; 2(1): 161-173.

Indo Global Journal of Pharmaceutical Sciences( ISSN 2249 1023; CODEN- IGJPAI; NLM ID: 101610675) indexed and abstracted in CrossRef (DOI Enabling), CNKI, UGC CARE Journal List, EMBASE (Elsevier), National Library of Medicine (NLM) Catalog (NCBI), ResearchGate, Publons (Clarivate Analytics), CAS (ACS), Index Copernicus, Google Scholar and many more. For further details, visit http://iglobaljournal.com 